\title{
Estimation of Avoidable Losses Due to Defoliators (Semilooper Complex and Common Cutworm, Spodoptera litura Fab.) in Different Varieties of Soybean
}

\author{
S. Ramesh Babu ${ }^{1 *}$, Ramgopal Dudwal ${ }^{2}$, Prahlad Kumar Meena ${ }^{1}$ and P. Rokadia ${ }^{1}$ \\ ${ }^{1}$ Agricultural Research Station, Maharana Pratap University of Agriculture and Technology \\ (MPUAT), Borwat Farm, Banswara-327 001 (Rajasthan), India \\ ${ }^{2}$ Division of Entomology, Pesticide Residue, Rajasthan, Agricultural Research Institution \\ (RARI), Durgapura, Jaipur-302 018 (Rajasthan), India
}

*Corresponding author

\section{A B S T R A C T}

\begin{tabular}{|c|}
\hline Keywords \\
\hline $\begin{array}{l}\text { Soybean, Spodoptera } \\
\text { litura, Yield loss, } \\
\text { Semilooper, JS-335, } \\
\text { RKS-24 }\end{array}$ \\
\hline Article Info \\
\hline $\begin{array}{l}\text { Accepted: } \\
17 \text { July } 2018 \\
\text { Available Online: } \\
10 \text { August } 2018\end{array}$ \\
\hline
\end{tabular}

An experiment was conducted during Kharif 2014 to 2016 at ARS, MPUAT, Banswara. The objective was to estimate avoidable losses due to defoliators in seed yield of soybean on four varieties viz., JS-335, JS-93-05, JS-95-60 and RKS-24.The semilooper population varied from 1.21 to 3.96 larvae/mrl on different soybean varieties. The maximum population was observed on JS-335 then JS-93-05 and JS-95-60 was significantly lower semilooper than that on RKS-24. Similarly, from the pooled data of three years, it is evident that the Spodoptera litura larval population varied from 1.54 to 4.77 larvae/mrl on different varieties of soybean. It was maximum on JS-335and minimum on JS-95-60 and JS-93-05. Under protected conditions, the minimal S. litura larval incidence of less than one larva/mrl was observed in all the soybean varieties. From the data it was evident that maximum yield loss in JS-335 during 2014 and 2016 corresponded with the maximum population of semilooper and S. litura larvae.

\section{Introduction}

Soybean (Glycine max Merrill) is one of the most important oil seed crops grown in India. It contains a high amount of quality protein (42\%) and 20\% oil rich in lycine and vitamins A, B and D (Jain et al., 2017). It is the fifth largest oilseed crop in India next only to castor, safflower, groundnut and rapeseedmustard (Sinha and Netam, 2013). Soybean is mainly grown in USA, Brazil, China, Argentina and India among them USA stands first with an area of about 76.53 million acres (Anonymous, 2012). Rajasthan has become third soybean growing state in India and shares 11.63 per cent overall production of soybean in the country next to Madhya Pradesh (57.13\%) and Maharashtra (24.46\%). The area of about 11.67 million hectares with a production of 8.59 million tonnes and productivity of $737 \mathrm{~kg}$ per hectare during Kharif-2015-2016 under soybean in the country (Anonymous, 2017). In Rajasthan, this crop is cultivated in about 1.20 million hectares area with the production of 804066 
tonnes and an average productivity of $667 \mathrm{~kg}$ per hectare (Anonymous, 2015-16). The productivity of soybean is less as compared to world average (1.8 tonne ha- 1 ) and this is due to several biotic and abiotic factors during the crop growth period (Sinha et al., 2013).

About 380 species of insects have been reported on soybean crop from many parts of the world. In India, soybean is reported to be attacked by as many as 275 insect species (Patil et al., 2014 and Kambrekar et al., 2017). Girdle beetle, Oberea brevis Swed., jassids, Empoasca sp.; whitefly, Bemisiatabaci; defoliators like Bihar hairy caterpillar, Spilosoma (Diacrisia) oblique (Walker); semiloopers [Thysanoplusia (=Trichoplusia) orichalcea (Fab.); Chrysodeixis eriosoma (Walker); Gesoniagemma (Swinhoe); Mocisundata (Fab.)] and common cutworm, Spodoptera litura (Fab.) were common in this Zone IVb of Rajasthan (Ramesh Babu et al., 2017). Among them, semiloopers are serious, devastating pests in which immature stages larvae feed on the vegetative and reproductive stages which results in complete defoliation and in case of severe infestation, complete devastation of soybean crop occurs. Common cutworm, Spodoptera litura Fabricius (Lepidoptera: Noctuidae) is a serious another devastating polyphagous pest causing huge losses (Singh and Jalali, 1997). Larvae feeding on the soybean foliage often results in complete defoliation and complete devastation of crop. Yield losses in soybean are directly associated with higher larval densities and increased defoliation (GeonHwi et al., 2006).

The pest infestation varies depends on the agro-climatic conditions prevailed in the zone and to need to generate location specific information on damage by different defoliators. Thus, there is a need to estimate crop damage due to semiloopers and common cutworm in different soybean varieties. Keeping in view, the present work was formulated to study the infestation of semiloopers and common cutworm in different soybean varieties to generate location specify information on the damage and to identify the soybean varieties that suffer the minimum damage due to these defoliators.

\section{Materials and Methods}

The experiment was conducted during threekharif seasons from 2014 to 2016 at the research farm of Agricultural Research Station, Borwat Farm, Banswara, Rajasthan, India. Estimation of avoidable losses in seed yield of soybean was done on four major soybean varieties viz., JS-335; JS-95-60; JS93-05 and RKS-24. The experiment was laid out in randomized block design, with two different treatments viz., protected and unprotected. The crop was sown in the last week of June or first week of July. Plot size was kept at $3 \times 3 \mathrm{~m}$ and there were three replications for each soybean varieties with 3 each for protected and unprotected conditions.

Under protected conditions, each soybean varieties were treated with imidacloprid 600 FS $\{48 \%$ (w/v) $\} @ 1.5 \mathrm{ml} / \mathrm{kg}$ seed and also kept free from the attack of insect pests by spraying it two times with triazophos 40 EC @ $800 \mathrm{ml} / \mathrm{ha}$ and chlorantraniliprole $18.5 \mathrm{SC}$ at 15 days interval. Whereas, only water spray was given in the unprotected conditions.

Weekly observations were taken in per row meter length on semilooper and Spodoptera litura larvae population from each plot. Data on yield per plot were recorded and converted into yield per hectare basis from protected and unprotected plots and the avoidable losses was calculated.

The avoidable yield loss due to pest was worked out by using following formula of Pradhan (1969).

(T-UT) 
Per cent avoidable loss in yield $=-\frac{------}{\mathrm{x}} 100$
$\mathrm{~T}$

Where, $\mathrm{T}=$ seed yield in treated plots, UT= seed yield in untreated plots.

Data obtained were subjected to analysis of variance (ANOVA) after transformation of data and data were analyzed with the help of web based software, Wasp (WEB AGRI STAT PACKAGE).

\section{Results and Discussion}

\section{Incidence of semiloopers under protected} and unprotected conditions

In 2014, the semilooper larval incidence per meter row length $(\mathrm{mrl})$ in soybean varied from 1.99 to 5.55 in the unprotected condition while the protected condition was significantly different and recorded low larval incidence from 0.00 to 0.11 per mrl. The maximum larval population of was recorded inRKS-24variety, while minimum damage was in JS-95-60 under unprotected conditions (Table 1).

Similarly, in 2015 and 2016, soybean varieties, JS-335, JS-95-60, JS-93-05 and RKS-24 recorded semilooper larval incidence per mrl of (4.55; 3.22), (2.22; 1.22), (1.10; $0.55)$ and $(4.10 ; 2.41)$, respectively, under unprotected condition while under protected condition all the soybean varieties had traces of larval population of semiloopers (Table 1).

From the pooled data of three years, it is evident that the semilooper population varied from 1.21 to 3.96 larvae $/ \mathrm{mrl}$ on different soybean varieties (Table 4). The maximum population of 3.96larvae/mrl was observed on JS-335. The semilooper population on the varieties, JS-93-05 and JS-95-60 (1.21 and $1.72 / \mathrm{mrl}$, respectively) was significantly lower than that on RKS-24.

Incidence of Spodoptera litura under

\section{protected and unprotected conditions}

During 2014, crop season the $S$. litura larval population varied from 1.55 to 4.77 larvae/mrl in the unprotected condition. The protected condition had traces of $S$. litura larval population infestation.

The minimum $S$. litura larval population of 1.55 larvae/mrl was observed on soybean variety, JS-95-60 while the maximum population on JS-335was (4.77 larvae/mrl) (Table 2). It was followed by RKS-24 (3.00 larvae/mrl).

In 2002-2003, again the minimum S. litura larval population of 1.53 to 1.55 larvae/mrl was observed on JS-95-60 and JS-93-05 while it was maximum on JS-335 (4.77 larvae/plant) in the unprotected condition. Almost the same trend was observed in 2016.

From the pooled data of three years (table 4), it is evident that the $S$. litura larval population varied from 1.54 to 4.77 larvae/mrl on different varieties of soybean. It was maximum (4.77 larvae/mrl) on JS-335and minimum (2.4 larvae/mrl) on JS-95-60 and JS93-05. Under protected conditions, the minimal $S$. litura larval incidence of less than one larva/mrl was observed in all the soybean varieties.

\section{Avoidable yield loss}

During 2014, the loss in the yield by semiloopers and S.litura varied from 42.20 to 42.68 per cent on JS-335 and JS-95-60, respectively (Table 3 ). However, no yield loss was observed in RKS-24 (Figure 1). In soybean variety, JS-335, the maximum yield loss corresponded with the maximum population of semilooper (4.11 larvae/mrl) and 4.77 larvae/mrl of $S$. litura under unsprayed conditions. 
Fig.1 Avoidable losses (\%) in different varieties of soybean during Kharif, 2014-2016

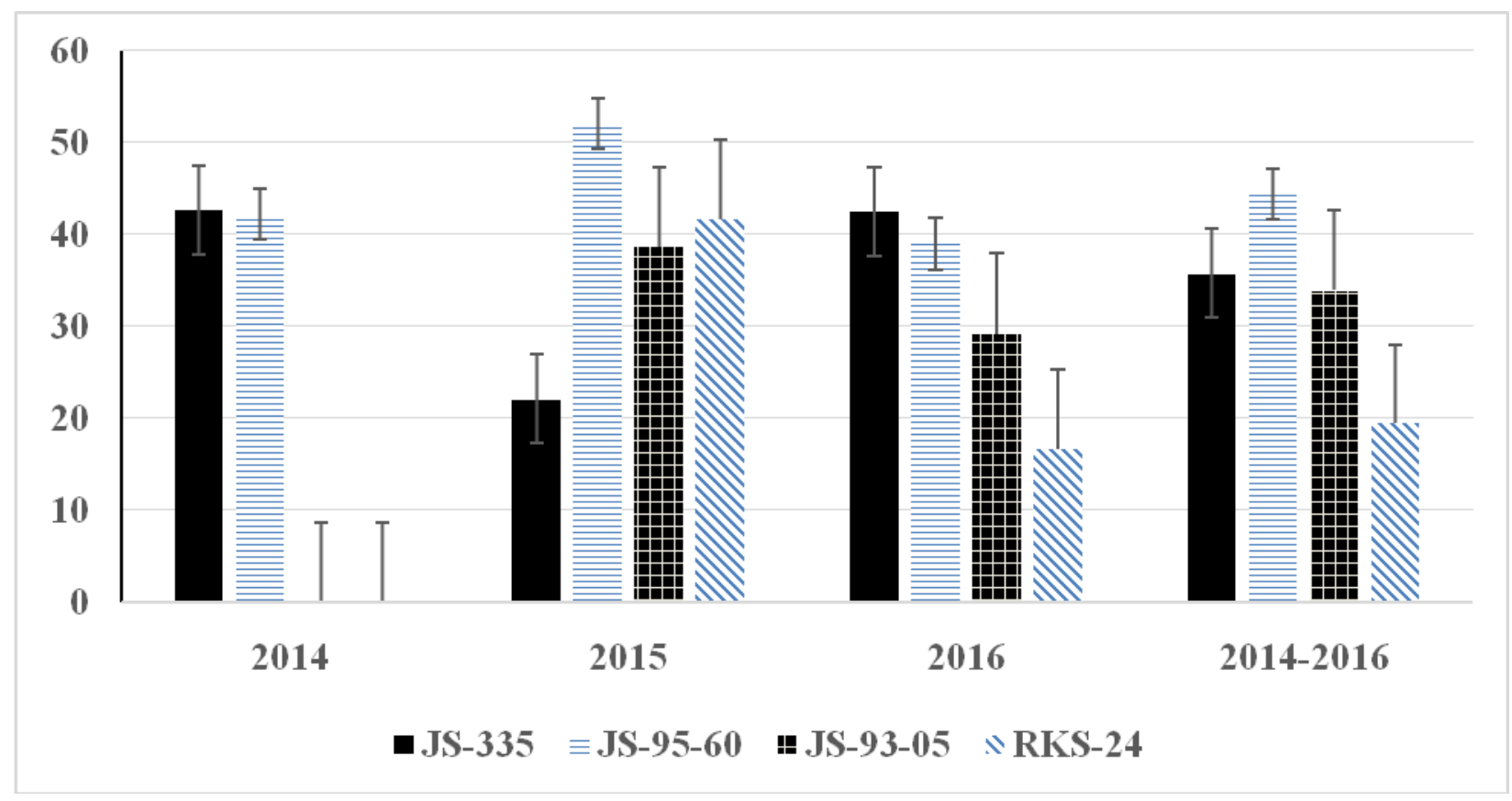

Table.1 Number of semilooper larvae per metre row length in different varieties of soybean from 2014 to 2016

\begin{tabular}{|c|c|c|c|c|c|c|c|c|c|}
\hline \multirow{3}{*}{$\begin{array}{l}\text { Soybean } \\
\text { Varieties }\end{array}$} & \multicolumn{9}{|c|}{ No. of larvae/ mrl } \\
\hline & \multicolumn{3}{|c|}{2014} & \multicolumn{3}{|c|}{2015} & \multicolumn{3}{|c|}{2016} \\
\hline & $\mathrm{P}$ & UP & Mean & $\mathrm{P}$ & UP & Mean & $P$ & UP & Mean \\
\hline JS-335 & $\begin{array}{c}0.00 \\
(0.70)^{*}\end{array}$ & $\begin{array}{c}4.11 \\
(2.14)\end{array}$ & $\begin{array}{c}2.05 \\
(1.42)\end{array}$ & $\begin{array}{c}0.22 \\
(0.84)\end{array}$ & $\begin{array}{c}4.55 \\
(2.24)\end{array}$ & $\begin{array}{c}2.38 \\
(1.54)\end{array}$ & $\begin{array}{c}0.11 \\
(0.77)\end{array}$ & $\begin{array}{c}3.22 \\
(1.92)\end{array}$ & $\begin{array}{c}1.66 \\
(1.34)\end{array}$ \\
\hline JS-95-60 & $\begin{array}{c}0.11 \\
(0.70)\end{array}$ & $\begin{array}{c}1.99 \\
(1.57)\end{array}$ & $\begin{array}{c}1.05 \\
(1.17)\end{array}$ & $\begin{array}{c}0.0 \\
(0.70)\end{array}$ & $\begin{array}{c}2.22 \\
(1.64)\end{array}$ & $\begin{array}{c}1.11 \\
(1.17)\end{array}$ & $\begin{array}{c}0.00 \\
(0.70)\end{array}$ & $\begin{array}{c}1.22 \\
(1.31)\end{array}$ & $\begin{array}{c}0.61 \\
(1.00)\end{array}$ \\
\hline JS-93-05 & - & - & - & $\begin{array}{c}0.33 \\
(0.91)\end{array}$ & $\begin{array}{c}1.10 \\
(1.26)\end{array}$ & $\begin{array}{c}0.72 \\
(1.08)\end{array}$ & $\begin{array}{c}0.00 \\
(0.70)\end{array}$ & $\begin{array}{c}0.55 \\
(1.02)\end{array}$ & $\begin{array}{c}0.27 \\
(1.02)\end{array}$ \\
\hline RKS-24 & $\begin{array}{c}0.00 \\
(0.70)\end{array}$ & $\begin{array}{c}5.55 \\
(2.44)\end{array}$ & $\begin{array}{c}2.77 \\
(1.58)\end{array}$ & $\begin{array}{c}0.33 \\
(0.91)\end{array}$ & $\begin{array}{c}4.10 \\
(2.14)\end{array}$ & $\begin{array}{c}2.21 \\
(1.52)\end{array}$ & $\begin{array}{c}0.11 \\
(0.77)\end{array}$ & $\begin{array}{c}2.41 \\
(1.70)\end{array}$ & $\begin{array}{c}1.26 \\
(1.25)\end{array}$ \\
\hline & $\begin{array}{c}0.03 \\
(0.72)\end{array}$ & $\begin{array}{c}3.88 \\
(2.05)\end{array}$ & & $\begin{array}{c}0.22 \\
(0.84)\end{array}$ & $\begin{array}{c}3.00 \\
(1.82)\end{array}$ & & $\begin{array}{c}0.05 \\
(0.74)\end{array}$ & $\begin{array}{c}1.85 \\
(1.49)\end{array}$ & \\
\hline Varieties & & & 0.19 & & & 0.10 & & & 0.13 \\
\hline Protection & & & 0.14 & & & 0.08 & & & 0.08 \\
\hline Interaction & & & 0.25 & & & 0.14 & & & 0.17 \\
\hline
\end{tabular}

Protected UP-Unprotected *Figures in parentheses are $\sqrt{ } \mathrm{X}+0.5$ transformed values 
Table.2 Number of Spodoptera litura larvae per metre row length in different varieties of soybean from 2014 to 2016

\begin{tabular}{|c|c|c|c|c|c|c|c|c|c|}
\hline \multirow{3}{*}{$\begin{array}{l}\text { Soybean } \\
\text { Varieties }\end{array}$} & \multicolumn{9}{|c|}{ No. of larvae/ mrl } \\
\hline & \multicolumn{3}{|c|}{2014} & \multicolumn{3}{|c|}{2015} & \multicolumn{3}{|c|}{2016} \\
\hline & $\mathrm{P}$ & UP & Mean & $P$ & UP & Mean & $\mathrm{P}$ & UP & Mean \\
\hline JS-335 & $\begin{array}{c}0.11 \\
(0.77)\end{array}$ & $\begin{array}{c}4.77 \\
(2.29)\end{array}$ & $\begin{array}{c}2.05 \\
(1.53)\end{array}$ & $\begin{array}{c}1.00 \\
(1.22)\end{array}$ & $\begin{array}{c}4.77 \\
(2.29)\end{array}$ & $\begin{array}{c}2.88 \\
(1.75)\end{array}$ & $\begin{array}{c}1.23 \\
(1.31)\end{array}$ & $\begin{array}{c}5.77 \\
(2.45)\end{array}$ & $\begin{array}{c}3.50 \\
(1.90)\end{array}$ \\
\hline JS-95-60 & $\begin{array}{c}0.33 \\
(0.89)\end{array}$ & $\begin{array}{c}1.55 \\
(1.42)\end{array}$ & $\begin{array}{c}1.05 \\
(1.16)\end{array}$ & $\begin{array}{c}0.00 \\
(0.70)\end{array}$ & $\begin{array}{c}1.53 \\
(1.31)\end{array}$ & $\begin{array}{c}0.76 \\
(1.01)\end{array}$ & $\begin{array}{c}0.66 \\
(1.05)\end{array}$ & $\begin{array}{c}2.22 \\
(1.32)\end{array}$ & $\begin{array}{c}1.44 \\
(1.32)\end{array}$ \\
\hline JS-93-05 & - & - & - & $\begin{array}{c}0.00 \\
(0.70)\end{array}$ & $\begin{array}{c}1.55 \\
(1.43)\end{array}$ & $\begin{array}{c}0.77 \\
(1.07)\end{array}$ & $\begin{array}{c}0.33 \\
(0.87)\end{array}$ & $\begin{array}{c}1.74 \\
(1.48)\end{array}$ & $\begin{array}{c}1.04 \\
(1.18)\end{array}$ \\
\hline RKS-24 & $\begin{array}{c}0.11 \\
(0.77)\end{array}$ & $\begin{array}{c}3.00 \\
(1.86)\end{array}$ & $\begin{array}{c}2.77 \\
(1.32)\end{array}$ & $\begin{array}{c}1.00 \\
(1.22)\end{array}$ & $\begin{array}{c}4.11 \\
(2.14)\end{array}$ & $\begin{array}{c}2.55 \\
(1.68)\end{array}$ & $\begin{array}{c}1.33 \\
(1.34)\end{array}$ & $\begin{array}{c}4.77 \\
(2.27)\end{array}$ & $\begin{array}{c}3.05 \\
(1.81)\end{array}$ \\
\hline & $\begin{array}{c}0.18 \\
(0.81)\end{array}$ & $\begin{array}{l}3.10 \\
1.86)\end{array}$ & & $\begin{array}{c}0.50 \\
(0.97)\end{array}$ & $\begin{array}{c}2.99 \\
(1.79)\end{array}$ & & $\begin{array}{c}0.89 \\
(1.14)\end{array}$ & $\begin{array}{c}3.62 \\
(1.95)\end{array}$ & \\
\hline Varieties & & & 0.21 & & & 0.29 & & & 0.39 \\
\hline Protection & & & 0.17 & & & 0.20 & & & 0.27 \\
\hline Interaction & & & 0.29 & & & 0.41 & & & 0.55 \\
\hline
\end{tabular}

Protected UP-Unprotected *Figures in parentheses are $\sqrt{ } \mathrm{X}+0.5$ transformed values

Table.3 Seed yield in different varieties of soybean under protected and unprotected conditions from 2014 to 2016

\begin{tabular}{|c|c|c|c|c|c|c|c|c|c|}
\hline \multirow{2}{*}{$\begin{array}{c}\text { Soybean } \\
\text { Varieties }\end{array}$} & \multicolumn{9}{|c|}{ Seed yield/ha } \\
& \multicolumn{3}{|c|}{2014} & \multicolumn{3}{c|}{2015} & \multicolumn{3}{c|}{2016} \\
\hline JS-335 & P & UP & Mean & P & UP & Mean & P & UP & Mean \\
\hline JS-95-60 & 22.64 & 10.11 & $\mathbf{1 3 . 8 7}$ & 23.48 & 18.30 & $\mathbf{2 0 . 8 9}$ & 23.24 & 16.33 & $\mathbf{1 9 . 7 8}$ \\
\hline JS-93-05 & - & - & - & 21.14 & 12.97 & $\mathbf{1 7 . 0 5}$ & 13.30 & 10.21 & $\mathbf{1 1 . 7 6}$ \\
\hline RKS-24 & 14.02 & 14.63 & $\mathbf{1 4 . 3 3}$ & 17.60 & 10.25 & $\mathbf{1 3 . 9 2}$ & 11.80 & 7.63 & $\mathbf{9 . 7 2}$ \\
\hline & 17.97 & 12.53 & & 20.16 & 12.07 & & 15.24 & 10.80 & \\
\hline Varieties & & & 2.28 & & & 3.51 & & & 2.23 \\
\hline Protection & & & 1.86 & & & 2.48 & & & 1.57 \\
\hline Interaction & & & 3.23 & & & 4.97 & & & 3.15 \\
\hline
\end{tabular}

Protected UP-Unprotected *Figures in parentheses are $\sqrt{ } \mathrm{X}+0.5$ transformed values 
Table.4 Population of defoliators (semilooper and S. litura) and seed yield in different varieties of soybean (pooled data from over a period of 3 years)

\begin{tabular}{|c|c|c|c|c|c|c|c|c|c|}
\hline \multirow[t]{3}{*}{$\begin{array}{l}\text { Soybean } \\
\text { Varieties }\end{array}$} & \multicolumn{3}{|c|}{$\begin{array}{c}\text { Semilooper } \\
\text { No. of larvae/ mrl }\end{array}$} & \multicolumn{3}{|c|}{$\begin{array}{l}\text { Spodoptera litura } \\
\text { No. of larvae/ mrl }\end{array}$} & \multicolumn{3}{|c|}{ Seed yield/ha } \\
\hline & \multicolumn{3}{|c|}{ 2014-2016 } & \multicolumn{3}{|c|}{$2014-16$} & \multicolumn{3}{|c|}{ 2014-16 } \\
\hline & $\mathrm{P}$ & UP & Mean & $\mathrm{P}$ & UP & Mean & $\mathrm{P}$ & UP & Mean \\
\hline JS-335 & $\begin{array}{c}0.11 \\
(0.78)\end{array}$ & $\begin{array}{c}3.96 \\
(2.10)\end{array}$ & 2.03 & 0.70 & 4.77 & 2.73 & 21.45 & 15.53 & 18.18 \\
\hline JS-95-60 & $\begin{array}{c}0.00 \\
(0.70)\end{array}$ & $\begin{array}{c}1.72 \\
(1.48)\end{array}$ & 0.86 & 0.00 & 1.54 & 0.77 & 15.53 & 7.89 & 11.71 \\
\hline JS-93-05 & $\begin{array}{c}0.14 \\
(0.80)\end{array}$ & $\begin{array}{c}1.21 \\
(1.30)\end{array}$ & 0.68 & 0.11 & 1.55 & 0.83 & 18.90 & 12.01 & 15.45 \\
\hline RKS-24 & $\begin{array}{c}0.14 \\
(0.80)\end{array}$ & $\begin{array}{c}4.02 \\
(2.12)\end{array}$ & 2.08 & 0.70 & 3.73 & 2.22 & 14.47 & 10.84 & 12.66 \\
\hline & 0.10 & 2.73 & & 0.37 & 2.90 & & 17.60 & 11.41 & \\
\hline Varieties & & & 0.39 & & & 0.87 & & & 1.30 \\
\hline Protection & & & 0.27 & & & 0.61 & & & 0.93 \\
\hline Interaction & & & 0.55 & & & 1.23 & & & 1.85 \\
\hline
\end{tabular}

Protected UP-Unprotected *Figures in parentheses are $\sqrt{ } \mathrm{X}+0.5$ transformed values

In 2015 , the yield loss in different chickpea varieties varied from 22.06 to 52.01 per cent and data are presented in (Figure 1).The maximum yield losses $(52.01 \%)$ in seed yield of soybean variety, JS-95-60 even though this variety had minimal larval population of semilooper and S. litura. This may be due to climatic conditions of the zone and also the short-duration nature of the variety. It was followed by RKS-24(41.70\%), JS-9305(38.65\%) and JS-335(22.06\%). In RKS-24, the maximum yield loss corresponded with the maximum population of semiloooer $(4.10$ larvae/mrl) and $S$. litura (4.11 larvae/mrl) under unsprayed conditions.

In 2016, the loss in seed yield of soybean varied from 16.67 per cent to as high as 42.45 per cent (Figure 1). The maximum loss $(42.45 \%)$ in JS-335 corresponded with the maximum population of semilooper (3.22 larvae/mrl) under unsprayed conditions, while the population of $S$. litura was 5.77larvae/mrl. The high loss in yield i.e. 38.96 and 29.19 per cent in JS-95-60and JS-93-05was observed even though low population of semilooper and S. litura larvae. Three years of pooled data on the seed yield of soybean and larval population of the semilooper and S.litura on different varieties are presented in table 4.

On the basis of three years of experiments, it can be stated that losses in various genotypes due to defoliators varied from 19.45 to 44.39 per cent. The genotype, JS-95-60suffered the maximum loss in seed yield $(44.39 \%)$. It was followed by JS-335(35.73\%), JS-9305(33.92\%) and RKS-24(19.45\%) (Figure 1).

The population of the semilooper varied from 1.21 to 4.02larvae/mrl under unprotected conditions. This aphid population was significantly lower in JS-93-05 and JS-95-60 than other soybean varieties. The population of the S.litura larvae varied from 1.54 to 4.77 larvae/mrl. The minimum population was observed in JS-95-60 and JS-93-05(1.54-1.55 larvae/mrl), which was significantly lower than other soybean varieties, JS-335 and RKS-24. 
From the data it was evident that maximum yield loss in JS-335 during 2014 and 2016 corresponded with the maximum population of semilooper and S. litura larvae.

In contradiction, JS-95-60 and JS-93-05 had low larval population of semilooper and S.litura but recorded higher yield losses in soybean seed yield. This may be due to varietal character and other environmental conditions. Moreover, soybean variety JS-335 has the ability to compensate the seed yield in spite of having higher population of semilooper complex and S.litura.

Ahirwar et al., (2014) reported avoidable seed yield losses due to insect pest complex of soybean from unprotected plot was recorded $14.84 \mathrm{q} / \mathrm{ha}$ as compared to protected plots $21.47 \mathrm{q} / \mathrm{ha}$. It clearly showed that when the crop was protected from insect pest complex, the yield losses may be avoided up to $30.8 \%$. Abudulai et al., (2012) reported that the yield loss in soybean ranged from 25.8 to 42.8 per cent in untreated plots.

The average seed yield of soybean obtained in protected and unprotected plot was 21.13 \& 22.86 and $13.37 \& 15.33 \mathrm{q} / \mathrm{ha}$, respectively which depicted that insect pests of soybean caused an average loss of 35.92 and 32.79 per cent equivalent to 7.76 and $7.53 \mathrm{q} /$ ha during 2003 and 2004, respectively (Padiwal, 2007).

It can be concluded from the present results that there was a significant reduction in the number of larvae per $\mathrm{mrl}$ of semilooper complex and Spodoptera liturain the protected plots when compare to unprotected plots due to the spraying of effective insecticides. Ultimately, there is an increase in soybean yield over unprotected plots and about 20-45\%losses in seed yield of different varieties of soybean can be avoided by taking proper control measures against semiloopers and S. litura.

\section{References}

Abudulai, M., B. S. Abdulai, O. A. Danial, M. Haruna, N. D. Nicholas and I. I. Y. Baba (2012). Yield loss at the different growth stages in soybean due to insect pests in Ghana. Phytopathology and Plant Protection, 45: 1796-1809.

Ahirwar K.C., Marabi R.S., Bhowmick A.K. 2014. Population dynamics of major Insect Pests and seed yield of Soybean. Annal of Plant Protection Sciences, 22(1): 56-59.

Anonymous (2012) Acreage National Agricultural Statistics Service (NASS), Agricultural Statistics Board, United States Department of Agriculture http://www.nass.usda.gov/Statistics by_Subject/result.php? 972223B2858C-34E7-AB81-EF96B4749D7\& sector $=$ CROPS\&group $=$ FIELD $\% 20 \mathrm{CR}$ OPS\&comm $=$ SOYBEANS .

Anonymous (2015-16) Rajasthan Agricultural Statistics at a glance 2015-16, Commissioner ate of Agriculture, Rajasthan, Jaipur, p.240.

Anonymous (2017). Agricultural Statistics at a glance 2016. GoI, Ministry of Agriculture \& farmers Welfare, Department of Agriculture and Cooperation \& Farmers Welfare, Directorate of economics and statistics, p. 519.

GeonHwi, I., SoonDo, B., HyunJoo, K., SungTae, P. and ManYoung, C. 2006. Economic injury levels for the common cutworm, Spodoptera litura (Fabricius) (Lepidoptera: Noctuidae) on soybean. Journal of Applied Entomology, 45: 333337.

Kambrekar, D. N., Shamarao Jahagirdar and J. Aruna. 2017. Tetraniliprole- new diamide insecticide molecule featuring novel mode of action against soybean insect pests. Biochem. Cell. Arch. 17 (2): 801-804. 
Padiwal, N. K. 2007. Investigations on the Population Dynamics, Estimation of Losses and Management of Major Insect Pests of Soybean [Glycine max (L.) Merill.]. Thesis submitted to Maharana Pratap University of Agriculture and Technology, Udaipurin partial fulfillment of the requirement for the degree of Doctor of Philosophy in Agriculture (Entomology), Department of Entomology, Rajasthan College of Agriculture, Udaipur. Pp.98.

Patil M U, Kulkarni V and Gavkare O (2014) Evaluating the efficacy of novel molecules against soybean defoliators. The Bioscan 9, 577-80.

Pradhan S. Insect Pests of Crops. National Book Trust, New Delhi, India, 1969; p. 80.

Ramesh Babu, S., Prahlad Kumar Meena and Ramgopal Dudwal. 2017. Population dynamics of major defoliators (semiloopers and tobacco caterpillar) in soybean crop. Legume Research, 40 (1): 183-186

Singh, S. P. and Jalali, S. K. 1997. Management of Spodoptera litura (Fabricius) (Lepidoptera: Noctuidae). In J. A. Wightman and G.V. Ranga Rao, eds. Spodoptera litura in India: Proceeding of the National Scientists Forum on Spodoptera litura (F.). ICRISAT Asia.

Sinha, D. and Netam, H. K. (2013). Effect of Date of Sowing on Population Dynamics of Girdle Beetle in Soybean. Res. J. Agri. Sci., 4(3): 437-438.

Sinha, D., Sahoo, A. K. and Sonkar, K. (2013). Bio-efficacy of Insecticides against Caterpillar Pests of Soybean Crop. Res. J. Agri. Sci., 4(5/6): 609611.

\section{How to cite this article:}

Ramesh Babu, S., Ramgopal Dudwal, Prahlad Kumar Meena and Rokadia, P. 2018. Estimation of Avoidable Losses Due to Defoliators (Semilooper Complex and Common Cutworm, Spodoptera litura Fab.) in Different Varieties of Soybean. Int.J.Curr.Microbiol.App.Sci. 7(08): 3078-3085. doi: https://doi.org/10.20546/ijcmas.2018.708.328 